\title{
Shaykh Abdullah Fahim's Views on Salawat in a Psychological Perspective
}

\section{Pandangan Shaykh Abdullah Fahim Terhadap Salawat dalam Perspektif Psikologi}

\author{
Khairul Nizam bin Zainal Badri* \\ Pusat Pengajian Al-Mansoorah, Puchong, Selangor
}

Received September 01, 2021| Accepted August 12, 2021| Published December 15, 2021

\begin{abstract}
Psycho-religion is classified as the highest spiritual psychotherapy in the field of psychology. This is because the field involves religion that works to increase confidence thus speeding up the healing process. One of the therapies that fall into this category is the practice of reciting salawat. This practice is common in traditional institutions of learning institutions in the Malay world. In some places, this practice becomes part of the curriculum of study. Some recite it as remembrance, and some recite it in the form of melodic performances such as qasidah, hadrah and so on. This study, however, limited to the views of prominent educators in Malaya, Shaykh Abdullah Fahim (1869 - 1961) to practice reading the salawat. The main objective of this study is to look at Shaykh Abdullah Fahim's thoughts on salawat from a psychological perspective. This study uses a fully qualitative method. For data collection purposes, an archival approach was used. The conclusion of the study was made by using an inductive approach that is by summarizing the findings in general. The study found that the practice of salawat from the point of view of Shaykh Abdullah Fahim has potential development benefits in terms of emotions, behavior, and motivation.
\end{abstract}

Keywords: Shaykh Abdullah Fahim; salawat; psycho-religion; psychology

Abstrak: Psikoreligius tergolong psikoterapi spiritual tertinggi dalam bidang psikologi psikoterapi. Hal ini dikarenakan bidang tersebut melibatkan agama yang berfungsi untuk meningkatkan kepercayaan diri sehingga mempercepat proses penyembuhan. Salah satu terapi yang termasuk dalam kategori ini adalah praktik membaca salawat. Praktik ini sudah menjadi tradisi di lembaga-lembaga lembaga pembelajaran tradisional di dunia Melayu. Di beberapa tempat, praktik ini menjadi bagian dari kurikulum studi. Ada yang membacanya untuk dzikir, dan ada pula yang membacanya dalam bentuk sesajen seperti qasidah, hadrah dan sebagainya. Namun penelitian ini terbatas pada pandangan tokoh pendidik di Malaya, Syekh Abdullah Fahim (1869 - 1961) tentang amalan membaca salawat. Tujuan utama dari penelitian ini adalah untuk melihat pemikiran Syekh Abdullah Fahim tentang salawat dari perspektif psikologis. Penelitian ini menggunakan metode kualitatif penuh. Untuk tujuan pengumpulan data, pendekatan arsip digunakan. Kesimpulan penelitian dibuat dengan menggunakan pendekatan induktif yaitu dengan meringkas temuan secara umum. Studi ini menemukan bahwa praktik salawat dari sudut pandang

\footnotetext{
*Corresponding Author: Khairul Nizam bin Zainal Badri, email: knizamzbmaptam@ gmail.com, Pusat Pengajian Al-Mansoorah, Jalan Putra Perdana 5d/1, Taman Putra Perdana, 47100 Puchong, Selangor, Malaysia
} 
Syekh Abdullah Fahim memiliki potensi manfaat pengembangan dalam hal emosi, perilaku, dan motivasi.

Kata Kunci: Shaykh Abdullah Fahim; salawat; psiko-religius; psikologi

\section{Introduction}

This writing is limiting research to Malays educational leaders, Shaykh Abdullah Fahim (18691961). During his life, he served as a teacher and administrator at Madrasah Al-Hamidiyyah, Alor Setar, Kedah and Madrasah Idrisiah, Kuala Kangsar, Perak. He is the founder of Madrasah Dairat AlMaarif Al-Wataniyyah, Kepala Batas Penang. He was also a teacher to dignitaries, such as sultans and courtiers. Among them are Sultan Iskandar Shah (30th Sultan of Perak) and his son Sultan Idris Shah (33rd Sultan of Perak), and Tunku Abdul Rahman Putra Al-Haj (first Prime Minister of Malaysia). He was appointed the first Mufti of Penang in 1951 and served for 5 years (Fatwa, 2018).

When he became the mudir and mufti, he was often asked to write a preface or taqriz for a book publication. The fact is, many book writers enlisted his services to review and verify the contents of a book before it was published. In addition to gaining blessings, his name can also be considered a runaway to the sale of books. This is because of his highly respected position in society, as a pious figure in the field of science. In addition to writing the preface, he is also very fond of attaching the practice of reciting salawat. This practice is given in the form of a degree, which is permission to the reader to practice with it.

Psycho-religion is considered the highest spiritual psychotherapy in the group of psychotherapeutic psychology. This is because psycho-religion contains religious elements that can evoke hope, belief, faith, and the body's immune system thus speeding up the healing process. One of the therapies that is a healing practice is by reciting salawat (Sikwandi, 2016).

Salawat in terms of language refers to prayer, memory, remembrance, speech, reflection, love, blessings and praise (Rahmatullah, 2016). In terms of terminology, salawat is divided into 3 things, namely mercy and glory from Allah SWT to Rasulullah SAW; request for mercy and glory from the angels to Allah SWT for Rasulullah SAW; and the request and glory of those who believe in Allah SWT for Rasulullah SAW (Kamaluddin, 2016).

On the other hand, salawat is a proof of the love of Muslims for Rasulullah SAW. Such love produces energy in human beings. In addition, salawat is a sign of the greatness of Allah SWT, and as a mercy of Allah SWT to the people of the Prophet SAW. This is because with the practice of such recitation, then He rewards the people of His Beloved (Habibillah, 2014).

In the context of therapy, the practice of salawat chanted by the human voice becomes an amazing healing instrument, as it can lower stress hormones, activate natural endophin hormones, increase feelings of relaxation and distract from fear, anxiety and tension (Sikwandi, 2016). 
In the context of religion, the recitation of salawat is very important because it connects Muslims to Rasulullah SAW to reach the intercession of the Prophet SAW in the hereafter. The knowledge of Rasulullah SAW to his ummah is based on the many salawat recitations presented to the Prophet SAW. Therefore, to reach the intercession of the Prophet SAW, Muslims are encouraged to increase the recitation of salawat to the Prophet SAW at all times (Arifin, 2019).

For that reason, the recitation of salawat is made a compulsory practice in the traditional education system, especially before starting lessons. In the system of study known as halaqah, the recitation of salawat is also practiced with the aim of obtaining the blessings of knowledge. Halaqah means learning is held with the position of students in a circle around the teacher (Abidin et al., 2020).

In some educational institutions such as madrasahs, salawat is recited in the form of hadrah. The performance of salawat in the form of hadrah is said to be able to actualize the values of Islamic culture, apply good and polite behavior, and spread the values of goodness into society (Prihastuti, 2019).

The practice of reciting salawat has always been associated with benefits in life. Among them are lik; can cover shame, and ask for forgiveness, occupying the position of alms (being a substitute for alms), eliminate the nature of stinginess, and selfishness, getting instructions or inspiration to make something work (Kafadi, 2002). In another note, the practice of salawat motivates its readers in terms of; expanded sustenance, eliminated distress, prayers are granted (MZ, 1995). The practice of salawat in terms of psychology can benefit from the following angles; brings happiness, brings peace of mind, increase creativity, and give confidence to solve problems (Olivia, 2016)

\section{Methodology}

Therefore, the goal of this study is to find out his views on the practice of salawat and the advantages of practicing it. For the study to be more focused, the writing will look at the relevance of Shaykh Abdullah Fahim's views on the practice of salawat from a psychological point of view. This is because as mentioned above, salawat belongs to the field of psycho-religion.

This study uses a qualitative method. Archival-type studies were used to collect data in the form of documentation. The writings of Shaykh Abdullah Fahim in the form of degrees and poems related to the practice of salawat are the main objects of study. The study of documentation is to analyze the content of salawat certified by Shaykh Abdullah Fahim in books that were given a welcome speech by him, for example in a book written by Haji Zakaria bin Haji Abul Bakar entitled Izhar Al-Haqq fi Ilm Usul Al-Din wa Al-Figh and books authored by Muhammad Zain Al-Hajj Ibrahim entitled Suluhan Rasul. The rest is a study of his writings on salawat contained in a book entitled Sheikh Abdullah Fahim Ulama Melayu Progresif published by the Faculty of Islamic Studies Universiti Kebangsaan Malaysia. In concluding the results of the study, an inductive thinking approach is used which refers to the process of analysis that starts from specific matters and then draws conclusions that are general in nature (Moersalah \& Moersanef, 1987). 


\section{Result}

\section{Foreword by Shaykh Abdullah Fahim}

The work of Shaykh Abdullah can most be seen through the preface he wrote in a book. He started writing the preface while serving at Madrasah Idrisiah, Kuala Kangsar. Among the earliest preface written by Shaykh Abdullah Fahim is found in the book written by Shaykh Wan Abdul Rahman bin Wan Muhammad entitled Risalah Al-Dima 'Al-Kharijah Min Qubul Al-Nisa. This book was printed in $1354 \mathrm{H} / 1934 \mathrm{H}$ on the orders of Raja Ummu Kalsom, the Queen of Perak. At the beginning of this taqriz, Shaykh Wan Abdul Rahman stated the position of Shaykh Abdullah Fahim as his teacher with several titles as follows.

Taqriz ulama who is my teacher. Indeed, this servant's treatise was narrated by Ustaz Al-Fadhil Al-Kamil Al-Alim, teacher of al-an's servant (now), Shaykh Abdullah Fahim, Headmaster of Madrasah Al-Idrisiyyah Bukit Chandan Dar Al-Ridwan (Muhammad, 1934).

Shaykh Wan Abdul Rahman is one of the great scholars in the state of Perak. He was the son of Shaykh Wan Muhammad bin Wan Hussain (died in 1929), a Kelantan-born scholar who is considered the First Mufti of the Perak State Government and Palace Teacher to the Sultan of Perak (Samat, 2010).

Perhaps because of the humble attitude of Shaykh Wan Abdul Rahman in asking Shaykh Abdullah Fahim to write the foreword in his book, then Shaykh Abdullah Fahim has praised the scholar in the poem he wrote as follows.

Well done to that man

intend and do good deeds sincerely for the sake of Allah

Walking humbly advises man

Whoever is humble because of Allah is sure to get His pleasure

Shaykh Abdullah Fahim closed the opening words he composed on the Day of Arafah in $1352 \mathrm{H} / 1933$ AD, with a hadith which means,

There is no son of Adam unless he has in his head the wisdom controlled by the Angels. If he is humble, it will be said to the Angel, "increase his wisdom". If he exalts himself (arrogant), it will be said to the Angel "lower his wisdom" (Muhammad, 1934).

His influence at Madrasah Idrisiah was enormous. Despite having moved to Kepala Batas and held the position of Mufti, he is still considered a Headmaster at Madrasah Idrisiah. For example in a book written by Shaykh Muhammad Isa bin Ibrahim bin Al-Haj Muhammad Faqih Al-Rawi in 1956, entitled Ini Risalah Haji: Hazihi Risalah Masalik Al-Fajj Ila Manasik Al-Hajj, an introduction to his position in the preface stated as follows;

This is Taqriz Al-Alim Al-Kamil Al-Ustaz Shaykh Abdullah Fahim, Principal of the Arabic School Kuala Kangsar, Perak (Ibrahim, 1956).

Shaykh Abdullah Fahim wrote more preface when he became the Mufti of Penang. Most of the authors of the book who asked Shaykh Abdullah Fahim to write the preface, were from among his 
students and religious scholars from all over the country. Among the scholars who asked him to write an introduction were Shaykh Abdul Karim bin Shaykh Uthman Sarawak who wrote a book entitled Suluh Kemajuan and Shaykh Uthman Jalaluddin Penanti who wrote a book entitled AlDurrah Al-Nafi'ah fi Ashrat Al-Sa'ah.

\section{Salawat according to Shaykh Abdullah Fahim}

Salawat from the point of view of Shaykh Abdullah Fahim has a very high value and meaning to Muslims, in line with respect for the position of the Prophet SAW as the most noble creature of Allah SWT. Similarly, the lives of the Companions and Family Members of the Prophet SAW, who need to be glorified and emulated because they have all received the blessings and pleasure of Allah SWT. For that reason, Muslims need to pray for Rasulullah SAW together with the Companions and his family members, to get blessings in life in this world and in the hereafter as expressed in a nasyid composed by Shaykh Abdullah Fahim to welcome guests;

God always blesses the bearer of guidance and good news

And upon the perfect friends and family (Ghani et al., 2006).

When Shaykh Abdullah Fahim returned from Mecca to Malaya around 1916, the Malays were colonized by the British. To raise the spirit of nationalism among the Malays, he was composing qasidah, and nasyid later sung by students in school every day. According to him, there is no other way for the Malays to achieve success but in a way to strengthen faith and make the Prophet Muhammad as a means of life,

Our country radiates when peace prevails

The mind blossoms in the midst of the clarity of time

O God of the Universe Save Malaya

On the position of the trustworthy Prophet, Malaya, the land of all goodness and the earth that is tightly controlled (Ghani et al., 2006).

Shaykh Abdullah Fahim has composed a special nasyid about Salawat to Rasulullah SAW, which describes his deep love for the Prophet SAW. According to him, Muslims should salute the Prophet SAW for his great service in conveying guidance on life in this world and the hereafter, and giving help in the Hereafter. The composition of the nasyid in question is as follows;

Pray for our praised intercessors

Pray and greet him perfectly

Honor the birthday of the chief of mankind

Praise the Prophet for the pride of this people

Pray for this chosen Prophet

Pray for this chosen Prophet

Pray for the bearer of glad tidings and warnings

Pray over the Prophet who was called to get up while he was covered (Ghani et al., 2006) 


\section{ljazah (Permission) of Reciting Salawat}

Apart from writing the preface, Shaykh Abdullah Fahim also sometimes attached salawat to be practiced by the readers. One of the salawat that is awarded to the reader is Salawat Al-Inqaz (Praying for Salvation). This salawat is narrated to have been compiled by Imam Al-Nawawi (631 H/1234 A.D.-676 H/1277 A.D.). According to Shaykh Abdullah Fahim, this salawat is good to practice so that all wishes are granted. The meaning of this Salawat is as follows,

O Allah, bestow mercy and prosperity on our chief, Muhammad, with salawat that solves my troubles, that relieves my burdens, that saves me from my deception, that removes my troubles and fulfills my desires.

This salawat was included by Shaykh Abdullah Fahim in a book written by his student, Muhammad Zain Al-Hajj Ibrahim entitled Suluhan Rasul (M. Z.-H. Ibrahim, 1950).

Another salawat organized by Shaykh Abdullah Fahim to be practiced is Salawat Al-Tibbiyyah which means Salawat of healing. This salawat was included by Shaykh Abdullah Fahim in a book written by Haji Zakaria bin Haji Abul Bakar entitled Izhar Al-Haqq fi Ilm Usul Al-Din wa Al-Fiqh. This book was published by a student of Shaykh Abdul Fahim named Haji Ahmad Hashimi, who was also the Mudir of Ma'ahad Al-Taqaddum Al-Watani in Pajak Song, in 1369 H/1949 A.D. The meaning of this salawat is,

O my Lord, salawat and greetings be upon our chief, Muhammad, a cure for all hearts, a cure for the body and light for sight and upon his family and his Companions (Ghani et al., 2006).

\section{Discussion}

\section{Salawat from a psychological point of view}

Salawat has an extraordinary power that is able to change a person's psychology in terms of way of thinking and feeling (Olivia, 2016). This is because salawat helps its readers to follow the behavior of Rasulullah SAW sincerely, without coercion. Salawat educates the heart to be gentle and sincere. With a deep love for Rasulullah SAW, the reader of salawat will obey all the commands and stay away from the prohibitions that he conveyed willingly (Al-Munajjid, 2017).

Salawat has a unique spiritual influence. It has elements that are able to reconstruct a person's level of consciousness so as to cultivate a sense of love for Allah and His Messenger, replace negative emotions and instill with the exemplary values of the Prophet SAW consisting of all qualities or levels of excellence (Schuon, 1987).

The salawat that is read regularly seems to be a meditation exercise to the reader that gives a sense of comfort to evoke calm and make the mind more focused. This conducive state helps the mind change to a process of thinking about positive things in life (Olivia, 2018).

In the context of psychobiology, such feelings of calm result because stress hormones have been successfully lowered. The occurrence of changes in the chemical system in the body has reduced blood pressure and heart rate. Wave activity in the brain becomes more controlled. This condition pushes the metabolic rate to run smoothly so that the emotions can be controlled well. 
The burden on the heart and the mind that is successfully shifted gives light and radiance to the eyes of the heart. This change in the eyes of the heart triggers a positive energy that gets rid of the reprehensible qualities that exist in the self, and replaces them with noble qualities (Tika, 2000).

The recitation of salawat performed collectively will develop a religious tradition. This is because the reading will usually be accompanied by learning such as reading books. In addition, the recitation of salawat is also able to increase the socio-cultural dimension when the relationship of brotherhood in society is closely intertwined (Wargadinata, 2010).

In the context of educational psychology, salawat plays a very large role in the spiritual development of students. Salawat fosters a sense of responsibility and a high level of awareness, builds good relationships among friends and respects teachers, performs worship on time and does it in congregation, and educates students to agree and work together in doing things. The spiritual development resulting from the practice of salawat can be seen through the table below (Niswah, 2017);

Table 1.

Function and Benefit of Salawat

\begin{tabular}{lll}
\hline \multicolumn{1}{c}{ Function } & \multicolumn{1}{c}{ Positive Value } & \multicolumn{1}{c}{ Benefit to Society } \\
\hline $\begin{array}{l}\text { Provide awareness of } \\
\text { responsibility }\end{array}$ & $\begin{array}{l}\text { Exercise trust and take on roles } \\
\text { to improve quality of life }\end{array}$ & Improving living standards \\
\hline Maintain good relationships & Remember each other & Caring about virtue \\
\hline Doing worship on time & $\begin{array}{l}\text { Concerned about time } \\
\text { management }\end{array}$ & Be an example of self-discipline \\
\hline $\begin{array}{l}\text { Strengthen the bond of } \\
\text { brotherhood }\end{array}$ & Decide by agreement & $\begin{array}{l}\text { Creating a culture of family and } \\
\text { not being hostile to each other }\end{array}$ \\
\hline
\end{tabular}

The salawat organized by Shaykh Abdullah Fahim to be recited always has a very big role from a psychological point of view, especially from a spiritual aspect. Salawat Tibbiyyah if read for example, can give well -being to the reader. Among its advantages are.

Enlighten the heart so that it can solve problems

Preserve oneself from the interference of evil

Paving the way to overcome difficulties that are sometimes unthinkable (Al-Hasany, 2014).

\section{Conclusion}

The British colonial powers allegedly pursued a policy that did not interfere with matters of religion and customs. But the colonizers had interfered in religious affairs and customs; by way of introducing a narrow state or tribal spirit that divides the unity of Muslims, and the application of the process of secularism by introducing the Western education system. These colonial policies introduced, subtly has left an impression epistemology eroded among the people of Malaya include among the Malays.

The framework of secularist thought that emptied nature and the human mind, of the divine element, and the introduction of a system of evaluation relative to religion have caused society to ignore the power of God and be confused with the true definition of progress and the realities of life. 
The paradigm of secularism has resulted in society being increasingly distant from religion and deceived by the meaning of progress proclaimed by the colonialists.

Shaykh Abdullah Fahim when returned to Malaya from Mecca around the year 1916 has seen the problem and trying to rebuild consciousness and spiritual power among the Malays through the introduction of the education system. One of the approaches in the education curriculum that is made routine is to recite salawat either in the form of nasyid or zikir.

Salawat is seen as the most effective medium because the features it has are able to attract readers to appreciate religious values. Its characteristics include rebuilding a special relationship with Rasulullah SAW and expecting an overflow of blessings and help from Allah SWT for the blessings and glory of Rasulullah SAW.

Basically, Shaykh Abdullah Fahim's thinking framework about salawat from a psychological point of view is divided into three main parts, namely in terms of reading, actions, and feelings. Reading salawat brings peace and well -being to the reader. Routine salawat practice can improve behavior and increase love for religion, race, and country. This thinking framework can be summarized in part in the following table.

The importance of routine of salawat are qauliah (recitation), Fi'liyyah (action) qalbiyyah (feeling). First, positive impact. Qauliah (tranquility and well -being), Fi'liyyah (self-discipline), and Qalbiyyah (confidence and appreciation). Second, quality of life. Oauliah (sharpen the mind), Fi'liyyah (time management), and Qalbiyyah (awareness of love of religion and homeland)

\section{References}

Abidin, M. Z., Ismail, H., Noh, A. M., \& Salleh, M. Y. (2020). Manifestasi kaedah halaqah pada zaman rasulullah saw:aplikasi dalam sistem pengajian pondok terpilih di negeri Kelantan. UMRAN - International Journal of Islamic and Civilizational Studies, 7(2), 51-67.

Al-Hasany, S. (2014). Keajaiban Selawat Menurut Al-Quran dan Hadis. Global Publishing.

Al-Munajjid, M. S. (2017). Cara nabi memperlakukan orang di berbagai level sosial. Pustaka Pelajar.

Arifin, L. (2019). Rasulullah kenal umatnya melalui selawat. Berita Harian.

Fatwa, B. (2018). Biografi Mufti-Mufti Negeri Pulau Pinang. Jabatan Mufti Negeri Pulau Pinang.

Ghani, Z. A., Talib, O., Zain, F. M., \& Jamsari, E. A. (2006). Syekh Abdullah Fahim Ulama Melayu Progresif. Fakulti Pengajian Islam Universiti Kebangsaan Malaysia.

Habibillah, M. (2014). Shalawat Pangkal Bahagia. Safirah.

Ibrahim, M. I. (1956). Ini Risalah Haji: Hazihi Risalah Masalik Al-Fajj Ila Manasik Al-Hajj. Zhi United Press.

Ibrahim, M. Z.-H. (1950). Suluhan rasul. Muhammad Hasan bin Ahmad.

Kafadi, N. M. (2002). Rahasia keutamaan dan keistimewaan shalawat. Pustaka Media.

Kamaluddin. (2016). Rahasia dahsyat shalawat keajaiban lafadz Rasulullah SAW. PT Serambi Distribusi.

Moersalah, \& Moersanef. (1987). Pedoman Penyusunan karya ilmiah. Angkasa. 
Muhammad, W. A. (1934). Risalah Al-Dima' Al-Khrijah Min Qubul Al-Nisa. Matba'ah Persama.

MZ, L. (n.d.). Keutamaan sholawat nabi. Bintang Usaha Jaya.

Niswah, O. M. (2017). Upaya pengembangan sikap spiritual remaja melalui kegiatan shalawat di media syaraffiyah sawahan madiun. Fakultas Tarbiyah dan IImu Keguruan, Jurusan Pendidikan Agama. Institut Agama Islam Negeri Ponorogo.

Olivia, R. (2016). Shalawat untuk Jiwa. Transmedia Pustaka.

Olivia, R. (2018). Terapi segitiga cinta. Transmedia Pustaka.

Prihastuti, D. R. (2019). Pelaksanaan kegiatan ekstrakurikuler hadrah al-banjari dalam mengaktualisasikan nila-nilai kebudayaan islam sebagai wujud membentengi diri terhadap budaya asing Di MAN 1 Magetan. Fakultas Tarbiyah Dan Ilmu Keguruan Institut Agama Islam Negeri (IAIN) Ponorogo.

Rahim, R. A., \& Kahal, S. M. (2017). Ilmu kolonial dan islamisasi alam melayu: analisis kritikal. Sejarah, 26(1), 33-49.

Rahmatullah, M. A. (2016). Kitab lengkap shalat, dzikir, shalawat, dan doa terpopuler sepanjang tahun. Safirah.

Samat, T. (2010). Kenali tokoh berjasa Jilid 1. Pekan Ilmu Publications Sdn Bhd.

Schuon, F. (1987). The Spiritual significance of the substance of the prophet. crossroad.

Sikwandi, A. (2016). Pengaruh terapi sholawat nabi terhadap tingkat depresi pada lansia di UPT PSLU Bondowoso. Universitas Muhammadiyah.

Tika, A. (2000). The Amazing sholawat. PT Gramedia Pustaka Utama.

Wargadinata, W. (2010). Spritualitas Shalawat. UIN-Maliki Press. 
This page is intentionally left blank

Psikoislamika: Jurnal Psikologi dan Psikologi Islam 